\title{
ACE-FTS measurements of trace species in the characterization of biomass burning plumes
}

\author{
K. A. Tereszchuk ${ }^{1}$, G. González Abad ${ }^{1,4}$, C. Clerbaux ${ }^{2,3}$, D. Hurtmans ${ }^{3}$, P.-F. Coheur ${ }^{3}$, and P. F. Bernath ${ }^{1,5}$ \\ ${ }^{1}$ Department of Chemistry, University of York, Heslington, York, YO10 5DD, UK \\ ${ }^{2}$ UPMC Univ. Paris 06, Université Versailles St-Quentin, CNRS/INSU, LATMOS-IPSL, Paris, France \\ ${ }^{3}$ Spectroscopie de l'Atmosphère, Service de Chimie Quantique et de Photophysique, Université Libre de Bruxelles (U.L.B.), \\ Brussels, Belgium \\ ${ }^{4}$ Harvard-Smithsonian Center for Astrophysics, Atomic and Molecular Physics Division, Cambridge, MA 02138, USA \\ ${ }^{5}$ Department of Chemistry \& Biochemistry, Old Dominion University, Norfolk, VA 23529-0126, USA
}

Received: 15 March 2011 - Published in Atmos. Chem. Phys. Discuss.: 10 June 2011

Revised: 15 November 2011 - Accepted: 25 November 2011 - Published: 7 December 2011

\begin{abstract}
To further our understanding of the effects of biomass burning emissions on atmospheric composition, we report measurements of trace species in biomass burning plumes made by the Atmospheric Chemistry Experiment Fourier Transform Spectrometer (ACE-FTS) instrument on the SCISAT-1 satellite. An extensive set of 15 molecules, $\mathrm{C}_{2} \mathrm{H}_{2}, \mathrm{C}_{2} \mathrm{H}_{6}, \mathrm{CH}_{3} \mathrm{OH}, \mathrm{CH}_{4}, \mathrm{CO}, \mathrm{H}_{2} \mathrm{CO}, \mathrm{HCN}, \mathrm{HCOOH}$, $\mathrm{HNO}_{3}, \mathrm{NO}, \mathrm{NO}_{2}, \mathrm{~N}_{2} \mathrm{O}_{5}, \mathrm{O}_{3}, \mathrm{OCS}$ and $\mathrm{SF}_{6}$ are used in our analysis. Even though most biomass burning smoke is typically confined to the boundary layer, some of these emissions are injected directly into the free troposphere via fire-related convective processes and transported away from the emission source. Further knowledge of the aging of biomass burning emissions in the free troposphere is needed. Tracer-tracer correlations are made between known pyrogenic species in these plumes in an effort to characterize them and follow their chemical evolution. Criteria such as age and type of biomass material burned are considered.
\end{abstract}

\section{Introduction}

Biomass burning has an important role in determining the composition of the Earth's surface and atmosphere, and in some regions, emissions to the atmosphere rival those from fossil fuel combustion. For nearly $40 \mathrm{yr}$ the scientific community has studied the emission of trace constituents from different types of fuel and associated atmospheric concentra-

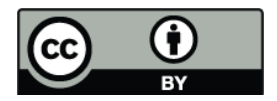

Correspondence to: K. A. Tereszchuk (keith.tereszchuk@york.ac.uk) tions, but our knowledge remains incomplete, reflecting the heterogeneous and stochastic nature of this process. The advent of space-borne observations of land-surface and tropospheric composition provided the first glimpse of the largescale impact of burning in the global troposphere, where biomass burning events represent an important source of gases and particles released into the atmosphere (Crutzen et al., 1979; Crutzen and Andreae, 1990; Andreae and Merlet, 2001).

Wildfires significantly alter air quality, sometimes on regional to hemispheric scales, and are an important component of the climate system. Biomass burning is, indeed, now recognized to be a major contributor to the global emissions of chemically-active trace gases and aerosols. A wide variety of pyrogenic species are emitted, including carbon dioxide $\left(\mathrm{CO}_{2}\right)$, carbon monoxide $(\mathrm{CO})$, methane $\left(\mathrm{CH}_{4}\right)$ plus a series of volatile organic hydrocarbons (VOCs), oxygenated volatile organic compounds (OVOCs) as well as nitrogen, sulfur and halogen-containing species, which are transformed by photochemical processes occurring during the first few hours in the plume. These molecules significantly alter the distribution of tropospheric ozone $\left(\mathrm{O}_{3}\right)$ and affect the oxidizing capacity of the atmosphere (Coheur et al., 2007).

The immediate goal of this work is to report and interpret the tropospheric mixing ratios of short and long-lived trace molecular species from biomass burning emissions obtained from infrared solar occultation measurements made with the Atmospheric Chemistry Experiment Fourier Transform Spectrometer (ACE-FTS) instrument on the SCISAT-1 satellite (Bernath et al., 2005). Tracer-tracer correlation calculations are carried out between known pyrogenic species

Published by Copernicus Publications on behalf of the European Geosciences Union. 
in an attempt to differentiate and characterize biomass burning emission both temporally as plumes evolve over time and qualitatively by comparing mixing ratios associated with different fuel types.

This preliminary work is part of an in-depth and more rigorous study being carried out in order to characterize biomass burning plumes remotely by considering criteria such as age and type of biomass material, and will be an integral facet of the Quantifying the impact of BOReal forest fires on Tropospheric oxidants over the Atlantic using Aircraft and Satellites (BORTAS) project (http://www.geos.ed.ac.uk/research/ eochem/bortas/) to further our understanding of the impact of biomass burning on atmospheric chemistry. Included in this study will be the addition of new VOC and OVOC species including PAN (Allen et al., 2005), acetonitrile (Allen et al., 2011; Harrison et al., 2011) and acetaldehyde (Tereszchuk et al., 2011) to be retrieved by ACE-FTS to aid in plume differentiation and characterization. Additional goals of this study will be to validate aircraft and ground measurements made during the BORTAS flight campaign and to derive agedependent enhancement factors (Lefer et al., 1994), i.e. normalized excess mixing ratios (Hobbs et al., 2003), which will serve as constraints for chemical transport models (CTMs) that study the aging of biomass burning emissions in the free troposphere.

ACE-FTS is a high-resolution Fourier transform spectrometer used for remote sensing of the limb of the Earth's atmosphere down to $5 \mathrm{~km}$. ACE-FTS has wide spectral coverage in the infrared covering a continuous region from 750 to $4400 \mathrm{~cm}^{-1}$ and currently offers, through the recently released Version 3.0 dataset (http://www.ace.uwaterloo.ca), retrievals for 38 molecular species as well as their isotopologues, over a dozen of which are known primary pyrogenic species found in biomass burning. With the large suite of molecular species available, and providing near-global coverage, ACE-FTS is currently the most suitable remotesensing instrument for this type of detailed investigation.

Previous studies of biomass burning emissions have been performed using ACE-FTS (Rinsland et al., 2005, 2007; Coheur et al., 2007) as well as a variety of other spaceborne instruments (Turquety et al., 2009; Coheur et al., 2009; Glatthor et al., 2009; Torres et al., 2009). The initial work conducted using ACE-FTS studied the emission of longerlived primary pyrogenic species and their long-range transport to establish the effectiveness of ACE-FTS in measuring the emission of trace species from biomass burning (Rinsland et al., 2005). This work was followed up by a more extensive analysis of the elevated volume mixing ratios for numerous species emitted from young Boreal plumes, deriving emission factors and calculating tracer-tracer correlation coefficients to demonstrate their enhancement (Rinsland et al., 2007). Results from these works sparked interest in retrieving additional trace organic species from biomass burning such as ethene $\left(\mathrm{C}_{2} \mathrm{H}_{4}\right)$, propyne $\left(\mathrm{C}_{3} \mathrm{H}_{4}\right)$, formaldehyde $\left(\mathrm{H}_{2} \mathrm{CO}\right)$, acetone $\left(\mathrm{C}_{3} \mathrm{H}_{6} \mathrm{O}\right)$ and peroxyacetylnitrate, abbrevi- ated as PAN $\left(\mathrm{CH}_{3} \mathrm{COO}_{2} \mathrm{NO}_{2}\right)$, and were the first reported detections of these species using infrared solar occultation spectroscopy from satellites (Coheur et al., 2007).

Biomass burning releases primary pyrogenic gases and primary smoke particles whose characteristics and relative emissions depend on various factors including the particular type of material burned and the burning conditions, e.g. flaming or smoldering combustion (Koppmann et al., 2005). This has been demonstrated by Yokelson et al. (1997), where biomass samples from a variety of ecosystems were burned at the Intermountain Fire Sciences Laboratory in Missoula, Montana. Yokelson et al. (1997) measured the emission from the smoldering combustion of biomass with a Fourier transform infrared spectrometer (FT-IR) coupled to an open multipass cell. Numerous field campaigns have also been conducted in an effort to quantify and characterize emissions from biomass burning from different ecosystems such as the the work done by Yokelson et al. (2003) to study the emissions from nascent and aged plumes from the African savannah and the tropical forests of Amazonia in Brazil during the TROFFEE campaign during the 2004 dry season (Yokelson et al., 2007b); but given the highly variable emissions inherent to biomass burning, particularly between lofted and unlofted emissions, even from within a single fire type (Akagi et al., 2011; Burling et al., 2011), it is uncertain whether this type of detailed characterization can be carried out with space-borne measurements and has yet to be confirmed.

\section{Methodology}

\subsection{Plume identification}

In previous studies conducted with ACE-FTS on the identification of biomass burning plumes, carbon monoxide (CO) was the principal molecular species used to find occultations that sample biomass burning through enhanced concentrations of $\mathrm{CO}$ relative to the background. $\mathrm{CO}$ is a wellknown pyrogenic species with an atmospheric lifetime of $\sim 2$ months in the free troposphere. Because $\mathrm{CO}$ is also emitted from numerous anthropogenic sources, another long-lived species that is more specific to biomass burning was chosen for our work. Hydrogen cyanide (HCN) has a life time of $\sim 5$ months and is emitted almost entirely from biomass and biofuel combustion. Typical background concentrations for $\mathrm{HCN}$ in the free troposphere have been determined to be 0.225-0.250 ppb (Li et al., 2003; Singh et al., 2003). In our work, occultations with enhanced tropospheric concentrations of $\mathrm{HCN} \geq 0.350 \mathrm{ppb}$ were considered as measurements of biomass burning emissions.

\subsection{ACE-FTS data processing}

For this study, Version 3.0 of the ACE-FTS data was employed, specifically the retrieval data which has been interpolated onto a 1-km altitude grid. Details of the retrieval 


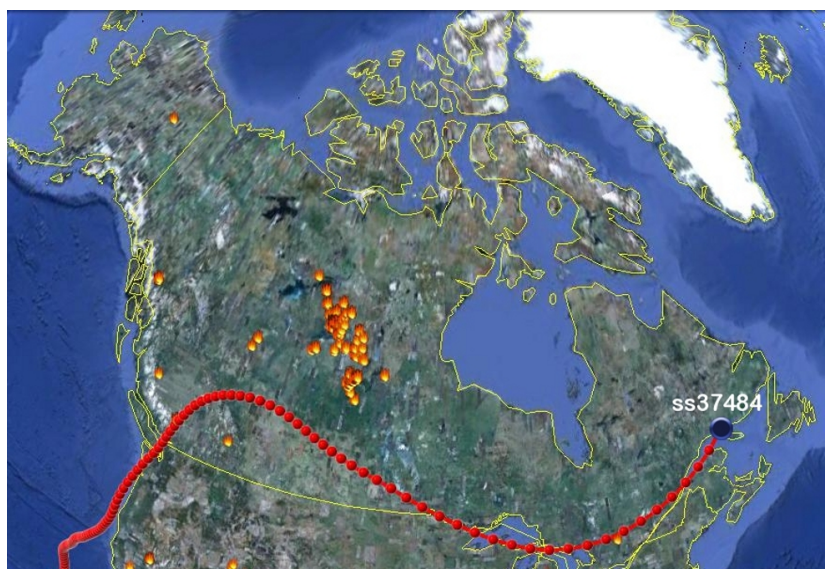

Fig. 1. A sample output of the trajectory data obtained using HYSPLIT. The 3-day back trajectory calculated from occultation ss37484 measured on 29 July 2010 is displayed in Google ${ }^{\mathrm{TM}}$ Earth with the instances of fire activity observed by MODIS over Canada on 27 July 2010. Spatial and temporal coincidences of the trajectory confirm that the emission source of the ACE-FTS measurement of enhanced $\mathrm{HCN}$ to be the widespread Boreal fires in northern Saskatchewan and parts of the Northwest Territories.

method, error budget and the piecewise quadratic interpolation of the data are outlined in Boone et al. (2005). To isolate retrievals made in the free troposphere, values for tropopause heights were obtained from derived meteorological products (DMPs) that were created using the ACE-FTS Version 3.0 dataset (Manney et al., 2007); all measurements above the altitude corresponding to the tropopause were filtered out. Data obtained from below the tropopause was then filtered by calculating the median values of each of the molecular species to be studied. Retrievals which contained measurements with molecular VMRs that were less than $10 \%$ of the median value at a given altitude were rejected as this usually indicates a failure in the retrieval. Cloud contamination is the biggest source of retrieval failure. ACE-FTS can effectively make measurements through thin clouds, but measurements of the free troposphere which contain thick clouds layers in the field of view (FOV) of the instrument can cause the retrieval to fail at these altitudes and the outcome of the retrieval is a deviation of the vertical profile to unrealistically low and even negative values for the VMR of a given molecular species. The median filtering seeks to eliminate all occultations which contain such a deviation to assure that the measurements being used are only those where the troposphere is cloudless during the time of measurement.

The remaining occultations which contained unrealistically large retrieval errors were also filtered out as they often indicate failed convergence in the retrieval. The remainder of the data was filtered by calculating the median absolute deviation (MAD) from the retrieval errors associated with the occultations; if the retrieval error at a given alti- tude was greater than 100 times the MAD value calculated from the dataset, they too were rejected. With the data thus filtered for any erroneous measurements, those occultations which contained $\mathrm{HCN}$ altitude profiles with concentrations of $\mathrm{HCN} \geq 0.350 \mathrm{ppb}$ were deemed measurements of biomass burning plumes and measurements with concentrations of $\mathrm{HCN} \leq 0.260 \mathrm{ppb}$ treated as non-biomass burning or off-plume measurements.

\subsection{Determination of emission sources}

Once plume measurements from the ACE-FTS dataset were identified, the origin of the biomass burning emissions that corresponds to each occultation which contain enhanced HCN was determined. To do this, fire data obtained from algorithm 1 of the Advanced Along Track Scanning Radiometer (AATSR) World Fire Atlas (Arino and Plummer, 2001) was used concertedly with the HYbrid Single-Particle Lagrangian Integrated Trajectory (HYSPLIT) (Draxler and Rolph, 2003) model. The altitudes corresponding to the maximum value for the concentration of HCN in the ACE-FTS retrieval profiles were used as the starting point in HYSPLIT to calculate back trajectories of the air mass from the point of measurement to recorded instances of biomass burning. In this way, the relative age of the plume can be determined with an accuracy of \pm 1 day. A typical example of plume identification from calculated back trajectories made with HYSPLIT is seen in Fig. 1, where the outflow from Boreal fires burning in northern Saskatchewan and parts of the Northwest Territories in Canada (27 July 2010) are measured over Maritime Canada 2 days later by ACE-FTS (sunset occultation ss37484). To validate the AATSR fire data, MODIS Terra and Aqua fire products archived by the University of Maryland (ftp://fuoco.geog.umd.edu) were also utilized to verify instances of biomass burning. It should be acknowledged that there is an inherent uncertainty in ground-level fire location (and thus age) associated with the fact that fires are often not detected as hotspots and can inject smoke at a variety of initial altitudes. To illustrate the problem of undersampling by active fire detection, the climatological cloud cover for July in western Canada is about 50\% (Stubenrauch et al., 2010), meaning many small fires can potentially go undetected by active fire detection and sources would be mislocated when relying on hotspots alone. To avoid any ambiguity in locations of these sporadic, individual hotspots, the ACE-FTS measurements used in this work are from outflows of substantial biomass burning events, where continued burning occurs in the same geographical region over an extended period time (days to weeks) such that numerous hotspots repeatedly appear, on a daily basis, within the same geographical area. Unfortunately, the caveat still exists that the potential emissions from undetected fires may invariable have a minor contribution to the plumes being sampled by ACE-FTS and thus introduce some uncertainty in the measurement. 


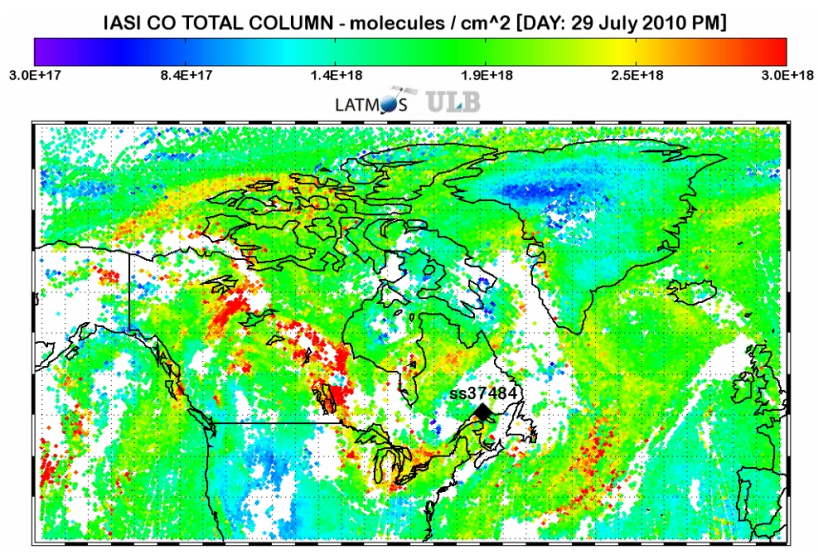

Fig. 2. IASI CO total column data for the evening orbit over North America on 29 July 2010. The figure shows the biomass burning outflow from numerous sources including Boreal fires in northern Saskatchewan and the Northwest Territories in Canada, a Siberian plume making its way eastward over Arctic Canada and a plume originating from China off the west coast of North America. The plume of elevated CO sampled by ss37484 in Fig. 1 is clearly visible over Maritime Canada and the path of the CO outflow emulates the HYSPLIT backtrajectory where the plume follows a southeasterly path from the source toward the Great Lakes and from there turns northeast in the direction of the Maritimes.

A visualization tool was required to bring ACE occultations, the AATSR and MODIS fire data and HYSPLIT trajectories together in order to facilitate the determination of the sources of biomass burning plumes. Scripts were written in Keyhole Markup Language (KML) in order to import the locations of ACE occultations and instances of fire activity into Google ${ }^{\mathrm{TM}}$ Earth along with the air mass trajectories from HYSPLIT, which conveniently provides the option for output into the KML format. An additional benefit of using Google ${ }^{\mathrm{TM}}$ Earth is that once the sources of biomass burning are geographically determined, one can visually inspect the region to help verify the type biomass material that is being burned. For example, a fire in the Amazon could be a deforestation fire, an understory fire, a crop residue fire on a plantation, or a pasture fire. Google ${ }^{\mathrm{TM}}$ Earth along with the concerted use of the Near-Real-Time Level2 Imager Data from the MODIS Rapid Response System (http://rapidfire.sci.gsfc.nasa.gov/realtime/?calendar), which contains the daily MODIS hotspots mapped onto the remote images, assist in visualizing the burn area to elucidate what material is actually contributing to the biomass emission and thus the homogeneity of the emissions being measured.

Since the HYSPLIT model can only serve to give a general indication of the direction of the movement of air masses at a given time, to further aid in the verification of the origin of biomass burning plumes, $\mathrm{CO}$ total column measurements from the Infrared Atmospheric Sounding Interferometer (IASI) on board the MetOp-A satellite (George et al.,

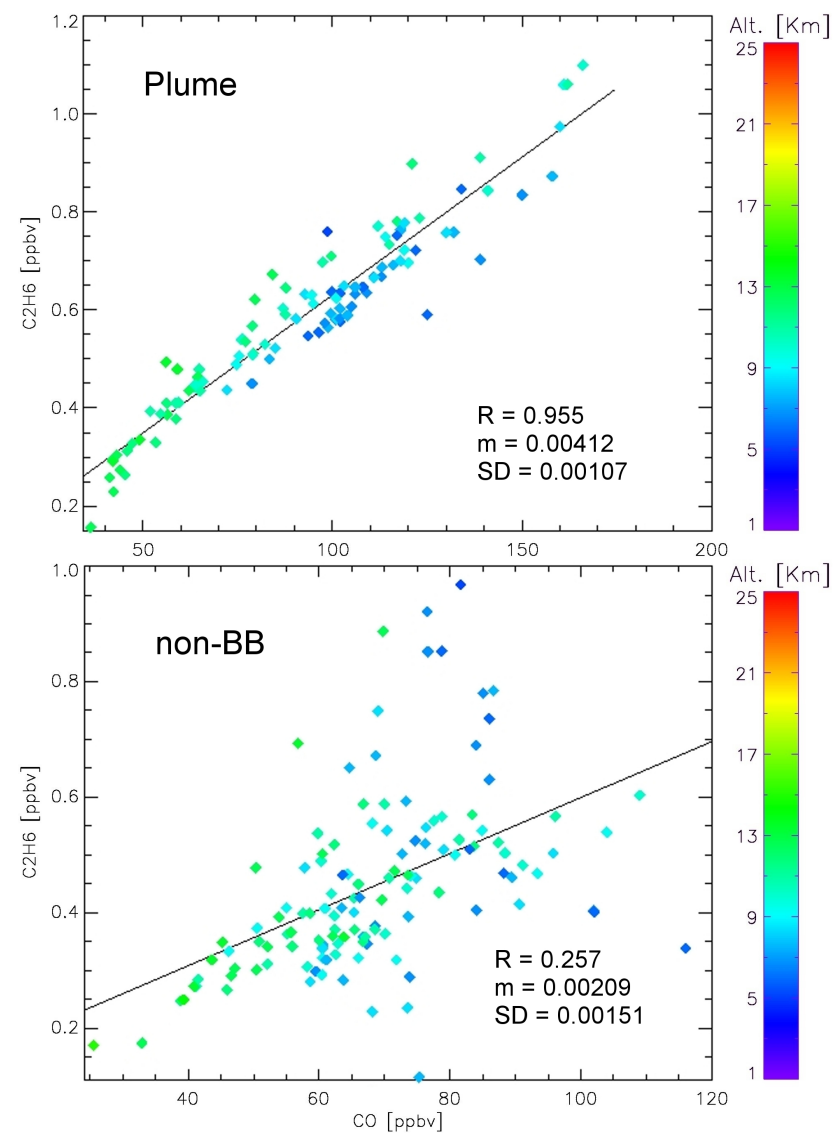

Fig. 3. $\mathrm{C}_{2} \mathrm{H}_{6}-\mathrm{CO}$ correlations for ACE-FTS measurements made in July 2008. (Upper panel) Correlations from approximately 30 occultations $(n=120)$ containing measurements of Boreal biomass burning plumes in Canada (2-3 days old). The high positive $(R)$ coefficient for $\mathrm{C}_{2} \mathrm{H}_{6}$ indicates its presence in the plume as a primary pyrogenic species. (Lower panel) Correlations of an equivalent number of off-plume, non-biomass burning measurements made during the same time period at similar latitudes.

2009; Clerbaux et al., 2009) were used to visualize the emission outflow from instances of biomass burning to validate the output calculated from the HYSPLIT backtrajectories and to ensure that measurements made by ACE-FTS are from a single origin and not a mixture of biomass burning outflows from different sources, which would compromise plume characterization. For example, plumes measured over the North Atlantic can come from a number of different sources since it is a region that corresponds to the confluence of numerous air masses. During the summer in the Northern Hemisphere, fire activity is prevalent in Canada, Alaska, Siberia and California. Simultaneous outflows from each of these regions will often converge over Eastern Canada and the North Atlantic, creating uncertainty in the analysis of plume origin and age. Figure 2 shows an example of IASI CO total column measurements made over Canada on 29 July 2010. In it, biomass burning plumes can be clearly seen over 
Table 1. Correlation coefficients $(R)$ of tracer-CO calculations made from approximately 30 ACE-FTS occultations $(n=120)$ of $2-3$ day old biomass burning plumes originating from a variety of geographical regions. Beneath each $R$ value is the slope of the linear regression, i.e. enhancement factor and the standard deviation of the slope calculation (in italics). Highlighted in each region are those molecules which correlate highly with $\mathrm{CO}(R$ value $\geq 0.80)$. Correlations performed on biomass burning emissions can be used effectively to differentiate plumes from different fuels due to their distinct chemical compositions and demonstrates the potential of remotely characterizing biomass burning from different sources.

\begin{tabular}{|c|c|c|c|c|c|c|c|c|c|c|c|c|c|}
\hline & $\mathrm{C}_{2} \mathrm{H}_{2}$ & $\mathrm{C}_{2} \mathrm{H}_{6}$ & $\mathrm{CH}_{3} \mathrm{OH}$ & $\mathrm{CH}_{4}$ & $\mathrm{H}_{2} \mathrm{CO}$ & $\mathrm{HCN}$ & $\mathrm{HCOOH}$ & $\mathrm{HNO}_{3}$ & $\mathrm{~N}_{2} \mathrm{O}_{5}$ & $\mathrm{NO}$ & $\mathrm{NO}_{2}$ & $\mathrm{O}_{3}$ & OCS \\
\hline Amazon & $\begin{array}{c}\mathbf{0 . 9 1 9} \\
0.00151 \\
0.00007\end{array}$ & $\begin{array}{c}\mathbf{0 . 9 5 2} \\
0.00563 \\
0.00018\end{array}$ & $\begin{array}{c}\mathbf{0 . 8 9 8} \\
0.01822 \\
0.00085\end{array}$ & $\begin{array}{l}\mathbf{0 . 1 1 3} \\
0.179 \\
0.146\end{array}$ & $\begin{array}{c}\mathbf{0 . 6 7 6} \\
0.00088 \\
0.00009\end{array}$ & $\begin{array}{c}\mathbf{0 . 9 6 2} \\
0.00364 \\
0.00011\end{array}$ & $\begin{array}{c}\mathbf{0 . 8 5 7} \\
0.00152 \\
0.00014\end{array}$ & $\begin{array}{c}\mathbf{0 . 2 2 0} \\
0.00011 \\
0.00049\end{array}$ & $\begin{array}{c}\mathbf{0 . 8 5 9} \\
0.00077 \\
0.00016\end{array}$ & $\begin{array}{c}\mathbf{0 . 3 5 9} \\
0.00041 \\
0.00018\end{array}$ & $\begin{array}{c}\mathbf{0 . 9 8 2} \\
0.00070 \\
0.00077\end{array}$ & $\begin{array}{c}-\mathbf{0 . 8 9 6} \\
-0.901 \\
0.091\end{array}$ & $\begin{array}{c}\mathbf{0 . 4 7 8} \\
0.00033 \\
0.00005\end{array}$ \\
\hline Congo & $\begin{array}{c}\mathbf{0 . 9 6 4} \\
0.00205 \\
0.00008\end{array}$ & $\begin{array}{c}\mathbf{0 . 9 3 0} \\
0.00629 \\
0.00034\end{array}$ & $\begin{array}{c}\mathbf{0 . 9 2 3} \\
0.01877 \\
0.00109\end{array}$ & $\begin{array}{l}\mathbf{0 . 0 3 8} \\
0.116 \\
0.240\end{array}$ & $\begin{array}{c}\mathbf{0 . 8 3 6} \\
0.00068 \\
0.00006\end{array}$ & $\begin{array}{c}\mathbf{0 . 9 6 3} \\
0.00553 \\
0.00022\end{array}$ & $\begin{array}{c}\mathbf{0 . 8 6 7} \\
0.00254 \\
0.00019\end{array}$ & $\begin{array}{c}-\mathbf{0 . 5 5 9} \\
-0.00089 \\
0.00026\end{array}$ & $\begin{array}{c}\mathbf{0 . 8 8 4} \\
0.00071 \\
0.00043\end{array}$ & $\begin{array}{c}\mathbf{0 . 0 8 5} \\
0.00010 \\
0.00032\end{array}$ & $\begin{array}{c}\mathbf{0 . 1 8 8} \\
0.00033 \\
0.00034\end{array}$ & $\begin{array}{c}-\mathbf{0 . 8 2 7} \\
-0.539 \\
0.081\end{array}$ & $\begin{array}{c}\mathbf{0 . 2 9 1} \\
0.00008 \\
0.00004\end{array}$ \\
\hline Savannah & $\begin{array}{c}\mathbf{0 . 8 9 9} \\
0.00128 \\
0.00009\end{array}$ & $\begin{array}{c}\mathbf{0 . 8 6 6} \\
0.00462 \\
0.00038\end{array}$ & $\begin{array}{c}\mathbf{0 . 8 6 4} \\
0.01042 \\
0.00174\end{array}$ & $\begin{array}{l}\mathbf{0 . 1 6 0} \\
0.392 \\
0.326\end{array}$ & $\begin{array}{c}\mathbf{0 . 6 8 0} \\
0.00145 \\
0.00023\end{array}$ & $\begin{array}{c}\mathbf{0 . 8 9 3} \\
0.00434 \\
0.00035\end{array}$ & $\begin{array}{c}\mathbf{0 . 8 6 2} \\
0.00234 \\
0.00040\end{array}$ & $\begin{array}{c}-\mathbf{0 . 8 3 6} \\
-0.00238 \\
0.00071\end{array}$ & $\begin{array}{c}\mathbf{0 . 8 4 6} \\
0.00142 \\
0.00027\end{array}$ & $\begin{array}{c}\mathbf{0 . 7 1 4} \\
0.00038 \\
0.00026\end{array}$ & $\begin{array}{c}-\mathbf{0 . 8 0 7} \\
-0.00029 \\
0.00070\end{array}$ & $\begin{array}{c}-\mathbf{0 . 9 7 9} \\
-1.649 \\
0.169\end{array}$ & $\begin{array}{c}\mathbf{0 . 0 4 7} \\
0.00020 \\
0.00007\end{array}$ \\
\hline non-BB & $\begin{array}{c}\mathbf{0 . 6 4 5} \\
0.00156 \\
0.00026\end{array}$ & $\begin{array}{c}\mathbf{0 . 3 5 5} \\
0.00307 \\
0.00112\end{array}$ & $\begin{array}{c}\mathbf{0 . 6 8 9} \\
0.00798 \\
0.00128\end{array}$ & $\begin{array}{l}\mathbf{0 . 3 1 2} \\
2.690 \\
1.082\end{array}$ & $\begin{array}{c}\mathbf{0 . 5 1 1} \\
0.00117 \\
0.00027\end{array}$ & $\begin{array}{c}\mathbf{0 . 0 3 0} \\
0.00047 \\
0.00022\end{array}$ & $\begin{array}{c}\mathbf{0 . 5 9 2} \\
0.00037 \\
0.00011\end{array}$ & $\begin{array}{c}-\mathbf{0 . 2 0 3} \\
-0.00107 \\
0.00086\end{array}$ & $\begin{array}{c}-\mathbf{0 . 0 7 5} \\
-0.00009 \\
0.00063\end{array}$ & $\begin{array}{c}\mathbf{0 . 5 3 6} \\
0.00033 \\
0.00037\end{array}$ & $\begin{array}{c}-\mathbf{0 . 1 9 6} \\
-0.00163 \\
0.00173\end{array}$ & $\begin{array}{c}-\mathbf{- 0 . 5 4 3} \\
-1.160 \\
0.238\end{array}$ & $\begin{array}{c}\mathbf{0 . 3 3 5} \\
0.00053 \\
0.00021\end{array}$ \\
\hline Boreal & $\begin{array}{c}\mathbf{0 . 7 6 7} \\
0.00144 \\
0.00018\end{array}$ & $\begin{array}{c}\mathbf{0 . 9 5 5} \\
0.00412 \\
0.00107\end{array}$ & $\begin{array}{c}\mathbf{0 . 8 2 6} \\
0.02642 \\
0.00596\end{array}$ & $\begin{array}{l}\mathbf{0 . 0 5 9} \\
0.165 \\
0.456\end{array}$ & $\begin{array}{c}\mathbf{0 . 8 5 2} \\
0.00111 \\
0.00028\end{array}$ & $\begin{array}{c}\mathbf{0 . 3 5 4} \\
0.00101 \\
0.00048\end{array}$ & $\begin{array}{c}\mathbf{0 . 9 3 8} \\
0.00265 \\
0.00105\end{array}$ & $\begin{array}{c}-\mathbf{0 . 8 9 4} \\
-0.00893 \\
0.00247\end{array}$ & $\begin{array}{c}-\mathbf{0 . 6 3 4} \\
-0.00162 \\
0.00140\end{array}$ & $\begin{array}{c}\mathbf{0 . 8 2 5} \\
0.00521 \\
0.00278\end{array}$ & $\begin{array}{c}-\mathbf{0 . 8 1 4} \\
-0.00276 \\
0.00151\end{array}$ & $\begin{array}{c}-\mathbf{0 . 8 7 1} \\
-3.177 \\
0.633\end{array}$ & $\begin{array}{c}\mathbf{0 . 0 1 9} \\
0.00021 \\
0.00046\end{array}$ \\
\hline non-BB & $\begin{array}{c}\mathbf{0 . 7 2 8} \\
0.00155 \\
0.00020\end{array}$ & $\begin{array}{c}\mathbf{0 . 2 5 7} \\
0.00209 \\
0.00151\end{array}$ & $\begin{array}{c}\mathbf{0 . 6 4 5} \\
0.03145 \\
0.00813\end{array}$ & $\begin{array}{l}\mathbf{0 . 5 1 5} \\
3.701 \\
1.143\end{array}$ & $\begin{array}{c}\mathbf{0 . 1 5 8} \\
0.00033 \\
0.00039\end{array}$ & $\begin{array}{c}\mathbf{0 . 1 5 7} \\
0.00022 \\
0.00027\end{array}$ & $\begin{array}{c}\mathbf{0 . 1 6 1} \\
0.00029 \\
0.00033\end{array}$ & $\begin{array}{c}-\mathbf{0 . 5 9 4} \\
-0.01805 \\
0.00521\end{array}$ & $\begin{array}{c}\mathbf{0 . 6 5 7} \\
0.00013 \\
0.00057\end{array}$ & $\begin{array}{c}\mathbf{0 . 3 0 5} \\
0.00144 \\
0.00109\end{array}$ & $\begin{array}{c}-\mathbf{0 . 4 6 5} \\
-0.00583 \\
0.00277\end{array}$ & $\begin{array}{c}-\mathbf{0 . 7 3 0} \\
-3.280 \\
0.570\end{array}$ & $\begin{array}{c}\mathbf{0 . 3 5 3} \\
0.00068 \\
0.00035\end{array}$ \\
\hline
\end{tabular}

Canada from fires in northern Saskatchewan and the Northwest Territories, a Siberian plume making its way eastward over Arctic Canada and a plume originating from eastern China is drifting towards the west coast of North America. To track the outflows from multiple sources, animations are create using measurements from the morning and evening passes of IASI to observe plume movement over a period of days leading up to the time of the ACE-FTS measurement to determine where the plume outflows are originating from and if the there is convergence from more than one source.

\subsection{Tracer-tracer correlations}

Tracer-tracer correlation studies were conducted using 15 different molecular species. The majority of these species such as, $\mathrm{C}_{2} \mathrm{H}_{2}, \mathrm{C}_{2} \mathrm{H}_{6}, \mathrm{CH}_{3} \mathrm{OH}, \mathrm{CH}_{4}, \mathrm{H}_{2} \mathrm{CO}, \mathrm{CO}, \mathrm{HCN}$, $\mathrm{HCOOH}, \mathrm{HNO}_{3}$ and $\mathrm{OCS}$, are known primary pyrogenic biomass burning species and have been previously studied with ACE-FTS. In addition to these, $\mathrm{NO}, \mathrm{NO}_{2}, \mathrm{~N}_{2} \mathrm{O}_{5}$ and $\mathrm{O}_{3}$ are investigated to observe the effect of biomass burning emission on tropospheric oxidants. Finally, $\mathrm{SF}_{6}$ was also included in the study. Although it was demonstrated by Rinsland et al. (2007) that $\mathrm{SF}_{6}$ does not correlate with the VMRs of species emitted from fires and that the $\mathrm{SF}_{6}$ mixing ratio is consistent with no significant $\mathrm{SF}_{6}$ emissions from biomass burning, we treat $\mathrm{SF}_{6}$ in this work as a reference species to identify any potentially anomalous results in our calculations.
Further data filtering was conducted during the correlation calculations where only the altitudes with values of $\mathrm{HCN} \geq 0.35 \mathrm{ppb}$ were used. Figure 3 is an example of a correlation of ethane $\left(\mathrm{C}_{2} \mathrm{H}_{6}\right)$ and $\mathrm{CO}$ for $2-3$ day old Boreal biomass burning plumes from July 2008. $\mathrm{C}_{2} \mathrm{H}_{6}$ is a known primary pyrogenic species emitted from biomass burning and the upper panel of Fig. 3 verifies its presence as it correlates highly with $\mathrm{CO}$ in plumes $(R=0.955)$ and poorly in the non-biomass burning measurements $(R=0.257)$ seen in the lower panel. The $R$ value represents the classic Pearson correlation coefficient and the standard deviation (SD) is the 1-sigma uncertainty of the slope calculation $(m)$. Since the value of the slope is calculated using measurements of trace species that are associated with the measurements of enhanced $\mathrm{HCN}$ in the biomass burning plumes, the slope value thus represents the enhancement factor (Lefer et al., 1994) between the two pyrogenic species. The enhancement factors are obtained to determine trends in the plume photochemistry and can potentially serve as constraints for CTMs to study the aging of biomass burning emissions in the free troposphere. Similar to the emission ratio (Andreae and Merlet, 2001), enhancement factors are also calculated by dividing the excess trace species concentrations measured in a fire plume by the excess concentration of a simultaneously measured reference gas. $\mathrm{CO}$ is used as the reference species in this study. To obtain these excess concentrations, the ambient background concentrations must be subtracted from the values measured in the plume. i.e. $\Delta \mathrm{X} / \Delta \mathrm{CO}$ where $\Delta \mathrm{X}$ indicates the value of $X_{\text {plume }}-X_{\text {background. }}$. Alternatively, the 
Table 2. Age comparisons of Canadian Boreal plumes from July 2010 listing the enhancement factor relative to $\mathrm{CO}([\Delta \mathrm{X}] /[\Delta \mathrm{CO}])$, for plumes 1-2 and 5-6 days old with the associated 1-sigma standard deviation. Calculations were made from approximately 15 occultations $(n=60)$ of plumes from each representative age. Ratios for the primary pyrogenic species relative to long-lived CO decrease over time as these species are destroyed mainly by reaction with $\mathrm{OH}$ as the plume ages, negative correlations are noted for $\mathrm{O}_{3}, \mathrm{NO}_{2}$ and $\mathrm{HNO}_{3}$ indicating destruction processes.

\begin{tabular}{lrrrr}
\hline Species & \multicolumn{2}{c}{ 1-2 Days Old } & \multicolumn{2}{c}{ 5-6 Days Old } \\
& Ratio & Std. Dev. & Ratio & Std. Dev. \\
\hline $\mathbf{C}_{\mathbf{2}} \mathbf{H}_{\mathbf{2}}$ & 0.00096 & $(0.00010)$ & 0.00082 & $(0.00020)$ \\
$\mathbf{C}_{\mathbf{2}} \mathbf{H}_{\mathbf{6}}$ & 0.00637 & $(0.00093)$ & 0.00612 & $(0.00056)$ \\
$\mathbf{C H}_{\mathbf{3}} \mathbf{O H}$ & 0.02397 & $(0.00811)$ & 0.02257 & $(0.00316)$ \\
$\mathbf{C H}_{\mathbf{4}}$ & 1.092 & $(0.398)$ & 0.844 & $(0.324)$ \\
$\mathbf{H}_{\mathbf{2}} \mathbf{C O}$ & 0.00085 & $(0.00014)$ & 0.00082 & $(0.00028)$ \\
$\mathbf{H C N}$ & 0.00249 & $(0.00047)$ & 0.00208 & $(0.00035)$ \\
$\mathbf{H C O O H}$ & 0.00306 & $(0.000412)$ & 0.00252 & $(0.00040)$ \\
$\mathbf{H N O}$ & -0.00623 & $(0.00138)$ & -0.00801 & $(0.00132)$ \\
$\mathbf{~ N O}$ & 0.00081 & $(0.00036)$ & 0.00367 & $(0.00165)$ \\
$\mathbf{N O} \mathbf{O}_{\mathbf{2}}$ & -0.00077 & $(0.00282)$ & -0.00210 & $(0.00243)$ \\
$\mathbf{O}_{\mathbf{3}}$ & -1.419 & $(0.193)$ & -2.269 & $(0.7066)$ \\
$\mathbf{O C S}$ & 0.00035 & $(0.00018)$ & 0.00015 & $(0.00046)$ \\
\hline
\end{tabular}

enhancement factor can be determined as the linear regression slope of the species concentration versus the reference species, which is how the enhancement factors were obtained in this work. The only difference between an emission ratio and enhancement factor is that emission ratios are calculated from measurements at the time of emission, i.e. plumes with an age of zero. The enhancement factor is the normalized excess mixing ratio (Hobbs et al., 2003) obtained from plumes which are non-nascent and have aged for a period of time.

\section{Results}

\subsection{Plume characterization}

ACE-FTS measurements for the months of July and October from 2004 to 2010 were analyzed in an effort to characterize biomass burning from different geographical regions found in both the Northern and Southern Hemisphere. The month of October falls within the burning season in the Amazon of South America and the Congo in central Africa, where slash-and-burn agriculture is prevalent. This month also coincides with a period of typically high fire activity in the Australian savannah. July is at the height of forest fire activity in Canada, Alaska, California and Russia, as well as parts the Mediterranean basin, particularly in Spain and Greece.

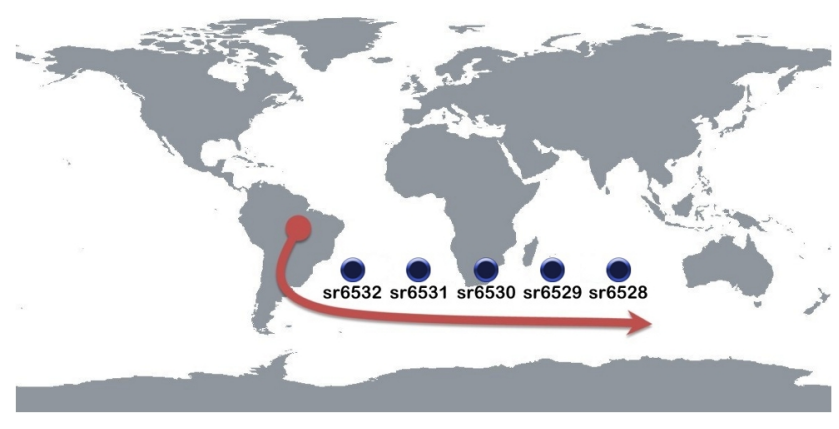

Fig. 4. Example of sequential ACE-FTS measurements sampling a continuous plume outflow originating from the tropical forests in Amazonia on 29 October 2004.

Table 1 gives a summary of $R$ coefficients from tracer-CO correlations calculated for sets of approximately 30 occultations $(n=120)$ of biomass burning plumes determined to be 2-3 days old from the the tropical forests of the Amazon in Brazil and the African Congo, the savannah grasslands of the Northern Territory of Australia and Boreal forests in Canada, respectively. The $n$ value reported represents the total number of data points, over all altitudes where $\mathrm{HCN}$ is enhanced, that are obtained from the occultations which are used in the correlation calculations. As a reference, offplume, non-biomass burning calculations were conducted using ACE-FTS measurements at similar latitudes during the same corresponding time periods. Beneath each $R$ value is the enhancement factor with respect to $\mathrm{CO}$ and the associated 1-sigma standard deviation (in italics). It's understood that there is high uncertainty in the exact vegetation type present at any given $1 \mathrm{~km}$ pixel in an area with rapid landuse change such as the Amazon or the African Congo, but for the purposes of this work, we seek to simply compare the remote, space-borne, measurements of distinct fuel types in order to determine whether differentiation between them is possible.

Highlighted in each ecosystem are those trace species which correlate highly with $\mathrm{CO}(R \geq 0.80)$. It is apparent that the biomass emissions from each of the four examples provided possess a distinct composition of trace gases such that they may be characterized by the differing correlation coefficients obtained from the emitted pyrogenic species. For example, biomass burning emission from the Congo shows a very high correlation for formaldehyde $\left(\mathrm{H}_{2} \mathrm{CO}\right)$, but the Amazon and Australian savannah do not. Plumes from the Amazon and Australian savannah can be distinguished from one another due to the high negative correlation that Australian plumes possess for nitric acid $\left(\mathrm{HNO}_{3}\right)$.

We can see from the correlations analysis for Boreal biomass burning in Canada and the savannah in northern Australia that, in addition to a high negative correlation for $\mathrm{O}_{3}$, negative correlations for nitrogen dioxide $\left(\mathrm{NO}_{2}\right)$ and nitric acid $\left(\mathrm{HNO}_{3}\right)$ are also evident and suggest that these species are undergoing or have undergone destruction 
Table 3. Tabulated mean concentrations (in ppb) and Tracer-CO correlations for selected trace species from the 5 sequential measurements of the Amazon plume depicted in Fig. 4. The associated standard deviation from the mean concentrations are given in parenthesis. For the correlations, $n \approx 8$ for each individual occultation, the enhancement factors with respect to CO are listed under their calculated $R$ values along with the standard deviation (in italics).

\begin{tabular}{|c|c|c|c|c|c|c|c|c|c|c|c|c|c|c|}
\hline & $\mathrm{CO}$ & $\mathrm{C}_{2} \mathrm{H}_{2}$ & $\mathrm{C}_{2} \mathrm{H}_{6}$ & $\mathrm{CH}_{3} \mathrm{OH}$ & $\mathrm{CH}_{4}$ & $\mathrm{H}_{2} \mathrm{CO}$ & $\mathrm{HCN}$ & $\mathrm{HCOOH}$ & $\mathrm{HNO}_{3}$ & $\mathrm{~N}_{2} \mathrm{O}_{5}$ & $\mathrm{NO}$ & $\mathrm{NO}_{2}$ & $\mathrm{O}_{3}$ & OCS \\
\hline \multicolumn{15}{|l|}{ Conc. } \\
\hline sr6532 & $\begin{array}{c}\mathbf{1 3 9 . 3} \\
(29.12)\end{array}$ & $\begin{array}{c}\mathbf{0 . 1 1 7} \\
(0.024)\end{array}$ & $\begin{array}{c}\mathbf{0 . 9 0 8} \\
(0.139)\end{array}$ & $\begin{array}{c}\mathbf{1 . 9 9} \\
(0.491)\end{array}$ & $\begin{array}{c}\mathbf{1 7 7 5} \\
(44.03)\end{array}$ & $\begin{array}{l}\mathbf{0 . 0 9 5 1} \\
(0.039)\end{array}$ & $\begin{array}{c}\mathbf{0 . 6 0 9} \\
(0.0886)\end{array}$ & $\begin{array}{c}\mathbf{0 . 1 3 8} \\
(0.0386)\end{array}$ & $\begin{array}{c}\mathbf{0 . 4 2 9} \\
(0.211)\end{array}$ & $\begin{array}{c}\mathbf{0 . 0 7 9 6} \\
(0.0472)\end{array}$ & $\begin{array}{c}\mathbf{0 . 0 6 6 3} \\
(0.0727)\end{array}$ & $\mathrm{n} / \mathrm{a}$ & $\begin{array}{c}\mathbf{8 9 . 2} \\
(20.3)\end{array}$ & $\begin{array}{c}\mathbf{0 . 3 9 9} \\
(0.0142)\end{array}$ \\
\hline sr6531 & $\begin{array}{c}\mathbf{9 2 . 5 3} \\
(23.90)\end{array}$ & $\begin{array}{c}\mathbf{0 . 0 8 0 2} \\
(0.0349)\end{array}$ & $\begin{array}{c}\mathbf{0 . 5 7 8} \\
(0.128)\end{array}$ & $\begin{array}{c}\mathbf{0 . 6 8 6} \\
(0.312)\end{array}$ & $\begin{array}{c}\mathbf{1 7 6 7} \\
(31.72)\end{array}$ & $\begin{array}{c}\mathbf{0 . 0 6 8 7} \\
(0.0463)\end{array}$ & $\begin{array}{c}\mathbf{0 . 4 0 3} \\
(0.0455)\end{array}$ & $\mathrm{n} / \mathrm{a}$ & $\begin{array}{c}\mathbf{0 . 2 9 1} \\
(0.152)\end{array}$ & $\begin{array}{c}\mathbf{0 . 0 3 5 6} \\
(0.0419)\end{array}$ & $\mathrm{n} / \mathrm{a}$ & $\mathrm{n} / \mathrm{a}$ & $\begin{array}{c}\mathbf{9 7 . 6} \\
(30.6)\end{array}$ & $\begin{array}{c}\mathbf{0 . 4 1 8} \\
(0.0161)\end{array}$ \\
\hline sr6530 & $\begin{array}{c}\mathbf{9 8 . 9 9} \\
(34.86)\end{array}$ & $\begin{array}{c}\mathbf{0 . 1 0 6} \\
(0.0543)\end{array}$ & $\begin{array}{c}\mathbf{0 . 5 3 7} \\
(0.170)\end{array}$ & $\begin{array}{c}\mathbf{1 . 1 9} \\
(0.746)\end{array}$ & $\begin{array}{c}\mathbf{1 7 6 4} \\
(23.66)\end{array}$ & $\begin{array}{c}\mathbf{0 . 0 5 6 7} \\
(0.0402)\end{array}$ & $\begin{array}{c}\mathbf{0 . 4 4 8} \\
(0.0660)\end{array}$ & $\mathrm{n} / \mathrm{a}$ & $\mathrm{n} / \mathrm{a}$ & $\begin{array}{c}\mathbf{0 . 0 3 3 3} \\
(0.0230)\end{array}$ & $\mathrm{n} / \mathrm{a}$ & $\mathrm{n} / \mathrm{a}$ & $\begin{array}{c}\mathbf{8 8 . 9} \\
(56.0)\end{array}$ & $\begin{array}{c}\mathbf{0 . 4 2 4} \\
(0.0125)\end{array}$ \\
\hline sr6529 & $\begin{array}{c}79.13 \\
(28.70)\end{array}$ & $\begin{array}{c}\mathbf{0 . 0 9 1 9} \\
(0.0664)\end{array}$ & $\begin{array}{c}\mathbf{0 . 5 4 5} \\
(0.179)\end{array}$ & $\begin{array}{c}\mathbf{0 . 8 7 5} \\
(0.651)\end{array}$ & $\begin{array}{c}\mathbf{1 7 3 3} \\
(43.49)\end{array}$ & $\begin{array}{c}\mathbf{0 . 0 3 2 2} \\
(0.0274)\end{array}$ & $\begin{array}{c}\mathbf{0 . 4 6 2} \\
(0.0870)\end{array}$ & $\begin{array}{c}\mathbf{0 . 0 7 2} \\
(0.0774)\end{array}$ & $\begin{array}{c}\mathbf{0 . 2 1 4} \\
(0.061)\end{array}$ & $\mathrm{n} / \mathrm{a}$ & $\mathrm{n} / \mathrm{a}$ & $\begin{array}{c}\mathbf{0 . 2 8 4} \\
(0.082)\end{array}$ & $\begin{array}{c}141 \\
(44.1)\end{array}$ & $\begin{array}{c}\mathbf{0 . 4 2 0} \\
(0.0225)\end{array}$ \\
\hline sr6528 & $\begin{array}{c}\mathbf{8 8 . 1 9} \\
(24.48)\end{array}$ & $\begin{array}{c}\mathbf{0 . 0 7 3 1} \\
(0.0373)\end{array}$ & $\begin{array}{c}\mathbf{0 . 5 5 7} \\
(0.142)\end{array}$ & $\begin{array}{c}\mathbf{0 . 7 8 7} \\
(0.408)\end{array}$ & $\begin{array}{c}\mathbf{1 7 6 7} \\
(46.50)\end{array}$ & $\begin{array}{c}\mathbf{0 . 0 6 2 9} \\
(0.0036)\end{array}$ & $\begin{array}{c}\mathbf{0 . 3 6 9} \\
(0.0970)\end{array}$ & $\mathrm{n} / \mathrm{a}$ & $\begin{array}{c}\mathbf{0 . 2 6 0} \\
(0.076)\end{array}$ & $\begin{array}{c}\mathbf{0 . 0 5 0 2} \\
(0.0498)\end{array}$ & $\begin{array}{c}\mathbf{0 . 0 1 0 2} \\
(0.0050)\end{array}$ & $\mathrm{n} / \mathrm{a}$ & $\begin{array}{c}\mathbf{9 6 . 0} \\
(28.5)\end{array}$ & $\begin{array}{c}\mathbf{0 . 4 2 6} \\
(0.0119)\end{array}$ \\
\hline \multicolumn{15}{|l|}{ Corr. } \\
\hline sr6532 & $\begin{array}{l}\mathbf{1 . 0 0 0} \\
1.000 \\
0.000\end{array}$ & $\begin{array}{c}\mathbf{0 . 9 7 3} \\
0.00088 \\
0.000079\end{array}$ & $\begin{array}{c}\mathbf{0 . 8 5 5} \\
0.00410 \\
0.00088\end{array}$ & $\begin{array}{c}\mathbf{0 . 8 0 2} \\
0.0135 \\
0.0036\end{array}$ & $\begin{array}{c}-\mathbf{0 . 3 8 4} \\
-0.581 \\
0.494\end{array}$ & $\begin{array}{c}\mathbf{0 . 4 4 1} \\
0.00059 \\
0.00043\end{array}$ & $\begin{array}{c}\mathbf{0 . 9 1 3} \\
0.00310 \\
0.00051\end{array}$ & $\begin{array}{c}\mathbf{0 . 4 0 9} \\
0.00054 \\
0.00043\end{array}$ & $\begin{array}{c}\mathbf{0 . 1 2 8} \\
0.00093 \\
0.0025\end{array}$ & $\begin{array}{c}\mathbf{0 . 6 2 8} \\
0.00105 \\
0.00053\end{array}$ & $\begin{array}{c}-\mathbf{0 . 0 5 9} \\
-0.00015 \\
0.00104\end{array}$ & $\mathrm{n} / \mathrm{a}$ & $\begin{array}{c}-\mathbf{0 . 1 9 2} \\
-0.1339 \\
0.2415\end{array}$ & $\begin{array}{c}\mathbf{0 . 7 0 0} \\
0.00034 \\
0.00014\end{array}$ \\
\hline sr6531 & $\begin{array}{l}\mathbf{1 . 0 0 0} \\
1.000 \\
0.000\end{array}$ & $\begin{array}{c}\mathbf{0 . 9 4 9} \\
0.00135 \\
0.00016\end{array}$ & $\begin{array}{c}\mathbf{0 . 9 7 5} \\
0.00509 \\
0.00041\end{array}$ & $\begin{array}{c}\mathbf{0 . 8 8 5} \\
0.01199 \\
0.00208\end{array}$ & $\begin{array}{l}\mathbf{0 . 5 3 6} \\
0.712 \\
0.354\end{array}$ & $\begin{array}{c}\mathbf{0 . 6 2 7} \\
0.00121 \\
0.00048\end{array}$ & $\begin{array}{c}\mathbf{0 . 9 7 5} \\
0.00336 \\
0.00012\end{array}$ & $\mathrm{n} / \mathrm{a}$ & $\begin{array}{c}\mathbf{0 . 7 2 6} \\
0.00483 \\
0.00130\end{array}$ & $\begin{array}{c}\mathbf{0 . 7 3 8} \\
0.00121 \\
0.00045\end{array}$ & $\mathrm{n} / \mathrm{a}$ & $\mathrm{n} / \mathrm{a}$ & $\begin{array}{c}-\mathbf{0 . 8 8 0} \\
-1.127 \\
0.193\end{array}$ & $\begin{array}{c}\mathbf{0 . 8 9 9} \\
0.00059 \\
0.00010\end{array}$ \\
\hline sr6530 & $\begin{array}{l}\mathbf{1 . 0 0 0} \\
1.000 \\
0.000\end{array}$ & $\begin{array}{c}\mathbf{0 . 9 8 1} \\
0.00144 \\
0.00011\end{array}$ & $\begin{array}{c}\mathbf{0 . 9 6 0} \\
0.00443 \\
0.00049\end{array}$ & \begin{tabular}{c|}
$\mathbf{0 . 9 3 3}$ \\
0.0199 \\
0.0027
\end{tabular} & $\begin{array}{c}\mathbf{0 . 0 7 7} \\
0.0523 \\
0.2393\end{array}$ & $\begin{array}{c}\mathbf{0 . 6 1 4} \\
0.00071 \\
0.00032\end{array}$ & $\begin{array}{c}\mathbf{0 . 8 9 4} \\
0.00293 \\
0.00024\end{array}$ & $\mathrm{n} / \mathrm{a}$ & $\mathrm{n} / \mathrm{a}$ & $\begin{array}{c}\mathbf{0 . 8 6 2} \\
0.00054 \\
0.00014\end{array}$ & $\mathrm{n} / \mathrm{a}$ & $\mathrm{n} / \mathrm{a}$ & $\begin{array}{c}-\mathbf{0 . 9 3 5} \\
-1.503 \\
0.201\end{array}$ & $\begin{array}{c}\mathbf{0 . 6 9 2} \\
0.00023 \\
0.00009\end{array}$ \\
\hline sr6529 & $\begin{array}{l}\mathbf{1 . 0 0 0} \\
1.000 \\
0.000\end{array}$ & $\begin{array}{c}\mathbf{0 . 9 7 7} \\
0.00219 \\
0.00034\end{array}$ & $\begin{array}{c}\mathbf{0 . 9 7 9} \\
0.00612 \\
0.00089\end{array}$ & $\begin{array}{c}\mathbf{0 . 9 9 4} \\
0.02253 \\
0.00175\end{array}$ & $\begin{array}{c}-\mathbf{0 . 6 4 0} \\
-0.970 \\
0.823\end{array}$ & $\begin{array}{c}\mathbf{0 . 9 9 8} \\
0.00095 \\
0.00004\end{array}$ & $\begin{array}{c}\mathbf{0 . 9 9 7} \\
0.00441 \\
0.00010\end{array}$ & $\begin{array}{c}\mathbf{0 . 9 6 9} \\
0.00261 \\
0.00047\end{array}$ & $\begin{array}{c}-\mathbf{0 . 6 2 0} \\
-0.00131 \\
0.00118\end{array}$ & $\mathrm{n} / \mathrm{a}$ & $\mathrm{n} / \mathrm{a}$ & $\begin{array}{c}\mathbf{0 . 9 8 4} \\
0.00282 \\
0.00035\end{array}$ & $\begin{array}{c}-\mathbf{0 . 6 7 1} \\
-1.033 \\
0.807\end{array}$ & $\begin{array}{c}\mathbf{0 . 6 9 7} \\
0.00055 \\
0.00040\end{array}$ \\
\hline sr6528 & $\begin{array}{l}\mathbf{1 . 0 0 0} \\
1.000 \\
0.000\end{array}$ & $\begin{array}{c}\mathbf{0 . 7 8 5} \\
0.00112 \\
0.00033\end{array}$ & $\begin{array}{c}\mathbf{0 . 9 8 3} \\
0.00532 \\
0.00038\end{array}$ & $\begin{array}{c}\mathbf{0 . 9 0 6} \\
0.01442 \\
0.00239\end{array}$ & $\begin{array}{l}\mathbf{0 . 2 9 0} \\
0.551 \\
0.606\end{array}$ & $\begin{array}{c}\mathbf{0 . 8 9 1} \\
0.00133 \\
0.00023\end{array}$ & $\begin{array}{c}\mathbf{0 . 9 9 6} \\
0.00389 \\
0.00009\end{array}$ & $\mathrm{n} / \mathrm{a}$ & $\begin{array}{c}\mathbf{0 . 2 8 7} \\
0.00089 \\
0.00099\end{array}$ & $\begin{array}{c}\mathbf{0 . 8 8 7} \\
0.00178 \\
0.00038\end{array}$ & $\begin{array}{c}\mathbf{0 . 4 9 6} \\
0.00010 \\
0.00007\end{array}$ & $\mathrm{n} / \mathrm{a}$ & $\begin{array}{c}-\mathbf{0 . 8 4 5} \\
-0.983 \\
0.207\end{array}$ & $\begin{array}{c}\mathbf{0 . 6 5 3} \\
0.00031 \\
0.00015\end{array}$ \\
\hline
\end{tabular}

processes in Boreal forest and savannah grassland fire emissions that are 2-3 days in age. To confirm the observations, Table 2 lists the enhancement factors for numerous trace species emitted from Boreal biomass burning. Values are compared between plumes 1-2 days old and those that are 5-6 days old. As would be expected, the values for the longer-lived primary pyrogenic species relative to $\mathrm{CO}$ decrease gradually over time as these species are slowly oxidized, mainly by reaction with $\mathrm{OH}$, as the plume ages. We again see negative correlations for $\mathrm{O}_{3}, \mathrm{NO}_{2}, \mathrm{HNO}_{3}$, indicating that these species have undergone a destruction process in the nascent plume such that concentrations of the reactive species have dropped below their off-plume values, supporting the results of the tracer-CO correlations for Boreal fires in Table 1 . The increased value for $\Delta \mathrm{X} / \Delta \mathrm{CO}$ that occurs between the 1-2 day old plumes and those that are 5-6 days old suggests that these species are being regenerated through chemical processes as secondary species in the aging plume and/or their concentration is re-equilibrating with the surroundings as the plume dilutes over time in the atmosphere.
As biomass burning plumes age, the emitted gaseous pyrogenic species within it react and chemical transformations of these primary pyrogenic species takes place leading to the formation of secondary species. Of these secondary species, $\mathrm{O}_{3}$ and $\mathrm{HNO}_{3}$ are particularly important. $\mathrm{HNO}_{3}$ is mainly formed by $\mathrm{OH}$-induced conversion of $\mathrm{NO}_{2}$, which results from rapid conversion of primary pyrogenic $\mathrm{NO}$. $\mathrm{NO}_{2}$ is also an important precursor to PAN which forms within a few hours. At low temperatures in the free troposphere, and in the presence of co-emitted $\mathrm{NH}_{3}, \mathrm{HNO}_{3}$ will quickly convert to ammonium nitrate $\left(\mathrm{NH}_{4} \mathrm{NO}_{3}\right)$ (Yokelson et al., 2009; $\mathrm{Al}$ varado et al., 2010). At night, $\mathrm{NO}_{2}+\mathrm{O}_{3}$ can make $\mathrm{NO}_{3}$ and $\mathrm{NO}_{2}$ plus $\mathrm{NO}_{3}$ can make $\mathrm{N}_{2} \mathrm{O}_{5}$, which can hydrolyze to make $\mathrm{HNO}_{3}$. If PAN or alkyl-nitrates form in the plume, warming of the plume can cause decomposition and release some $\mathrm{NO}_{2}$ in the aged plume as a secondary product. This may explain the results from Table 1 , which shows high negative correlations for $\mathrm{NO}_{2}$ in 2-3 day old emissions from the Boreal and savannah fires, but a high positive correlation in emissions from the Amazon. Organics emitted from biomass burning lead to the formation of secondary $\mathrm{O}_{3}$, an important atmospheric oxidant, and a precursor of $\mathrm{OH}$ radicals (Fiedler et al., 2009; Akagi et al., 2011). It is well known that reactions with the hydroxyl radical $(\mathrm{OH})$, the 
dominant oxidizing chemical in the atmosphere, drive atmospheric oxidation through reactions with species emitted from the Earth's surface. Many of these molecules lead to the chemical production of tropospheric $\mathrm{O}_{3}$ and other reactive trace gases (Rinsland et al., 2005).

The data in this work is preliminary and a more extensive analysis of the entire ACE-FTS dataset will be required before any specific chemical properties of biomass burning emissions in the free troposphere can be confirmed. Particularly with the potential retrieval of additional pyrogenic VOC and OVOC species such as PAN, which would assist in elucidating the $\mathrm{NO}_{\mathrm{x}}$ chemistry taking place. It would also be of particular interest to attempt to distinguish any potential differences in the day and nighttime chemistry within the plumes. It should be noted that in the correlation analysis conducted for this work, a mixture of both sunrise and sunset occultations were used in the calculations. Once a complete compilation is made of biomass burning measurements contained within the ACE-FTS dataset, efforts shall be taken to investigate the potential of ACE to provide additional information on day and nighttime plume chemistry. This differentiation may also account for the behavior of $\mathrm{NO}_{2}$ as seen in Table 1, where both high negative and positive correlations are observed for plumes of the same age.

Further exploring the capabilities of ACE-FTS to study the chemical evolution of biomass burning plumes, Fig. 4 shows an example of sequential measurements of a plume originating from the Amazon on 20 October 2004 that continuously flowed from the source over a period of several days. On 29 October 2004, 5 measurements were made in succession, 90 min between each measurement, sampling along the plume towards the source. The first measurement made was sr6528 where the age of the plume was approximately 8 days old, each successive measurement corresponds to a difference in age of about a day and the final measurement, sr6532, sampled the outflow when it was approximately 4 days old. Table 3 lists the tracer-CO correlation coefficients for each of the occultations and the mean concentrations (in ppb) of each of the trace species measured. The mean for each trace species is calculated from the values measured over all altitudes retrieved in each of the occultations where the $\mathrm{HCN}$ concentration is enhanced.

It is apparent from the concentrations in Table 3 that many of the known pyrogenic species emitted from biomass burning have elevated values which diminish over time as the plume ages and the outflow disperses eastwards. Understandably there is some fluctuation in concentration from measurement to measurement due to the fact that in each instance the measurement made may not have been at the exact center of the plume, but the overall trend is evident. Even from correlations calculated from the few data points obtained from the individual occultations, these molecules correlate with $\mathrm{CO}$ with high positive values indicating their presence as primary pyrogenic species. In occultation sr6529, one of the five successive measurements listed in Table 3, a high positive correlation is observed for $\mathrm{NO}_{2}(R=0.984)$, which corresponds to the results observed from the correlations of the Amazon plumes in Table 1 where a value of $R=0.982$ was obtained. The negative correlations obtained for $\mathrm{O}_{3}$ indicate that a destruction process has occurred in the nascent plume prior to the sequential measurements made by ACE-FTS where the plume has aged for a few days. The $\mathrm{O}_{3}$ concentrations in the non-nascent plume increase progressively with age and demonstrate a behavior similar to the Boreal plumes in Table 2 suggesting that the $\mathrm{O}_{3}$ is regenerating through chemical processes as secondary $\mathrm{O}_{3}$ in the aging plume and/or the concentration is simply re-equilibrating as the plume dilutes in the free troposphere. It should be noted that the $\mathrm{O}_{3}$ concentrations observed in the sequential measurements are substantially elevated above what are considered typical background concentrations for $\mathrm{O}_{3}$, which range from $40-80 \mathrm{ppbv}$ in the upper troposphere. For $\mathrm{O}_{3}$ to have a negative correlation relative to $\mathrm{CO}$, the off-plume concentrations for $\mathrm{O}_{3}$ must be quite high relative to the already elevated values observed in the sequential plume measurements. To validate these observations, the concentrations were compared to an off-plume measurement from the same time period and at similar latitudes. On the following day, 30 October 2004, sunrise occultation sr6555 made an off-plume measurement near the coast of Southern Australia (Lat: $-32.87^{\circ}$, Lon: $133.12^{\circ}$ ). The mean concentrations for the long-lived primary pyrogenic species $\mathrm{CO}$ and $\mathrm{HCN}$ were $35.30 \mathrm{ppbv}$ and $0.226 \mathrm{ppbv}$ respectively. The concentration obtained for $\mathrm{O}_{3}$ was $264.15 \mathrm{ppbv}$, much higher than the values reported from the sequential on-plume measurements and confirm our observations. It is apparent that the volatile, short-lived organic species emitted from the biomass burning activity in the Southern Hemisphere during the month of October 2004, prior to sequential measurements made by ACE-FTS, has elevated the relative background concentrations of $\mathrm{O}_{3}$ through the production of secondary $\mathrm{O}_{3}$.

\subsection{Emission factors}

One of the goals of this study is to calculate sets of agedependent enhancement factors for pyrogenic trace species from the remote measurements of biomass burning plumes, which can potentially serve as constraints for CTMs to study plume aging and evolution in the free troposphere. In an attempt to validate the enhancement factors obtained from the preliminary results of this study, emission factors relative to $\mathrm{CO}$ are calculated for long-lived primary pyrogenic species using the enhancement factors reported in Table 1. The enhancement factors are utilized as the effective emission ratios in the computation of the emission factors. Even though emission ratios are calculated from measurements taken at the time of emission, by using the enhancement factors obtained from long-lived species that are not readily reactive, we can make the approximation that the enhancement factor is equivalent to an emission ratio. 
Table 4. ACE emission factors relative to $\mathrm{CO}$ with associate standard deviation (in $\mathrm{g} \mathrm{kg}^{-1}$ ) compared to emission factors calculated from airborne measurements (Akagi et al., 2011) of Boreal forests in Canada, Amazon tropical forest and the savannah of the Northern Territory in Australia. Previously calculated Boreal emission factors made by Rinsland et al. (2007) using ACE-FTS measurements of Boreal fires in Canada are also included in the comparison.

\begin{tabular}{cccccccc}
\hline Trace Species & \multicolumn{3}{c}{ Canada Boreal Forest } & \multicolumn{2}{c}{ Amazon Tropical Forest } & \multicolumn{2}{c}{ Australia Savannah } \\
& $\mathrm{EF}\left(\mathrm{g} \mathrm{kg}^{-1}\right)$ & $\mathrm{EF}_{\text {Rinsland }}\left(\mathrm{g} \mathrm{kg}^{-1}\right)$ & $\mathrm{EF}_{\text {Akagi }}\left(\mathrm{g} \mathrm{kg}^{-1}\right)$ & $\mathrm{EF}\left(\mathrm{g} \mathrm{kg}^{-1}\right)$ & $\mathrm{EF}_{\mathrm{Akagi}}\left(\mathrm{g} \mathrm{kg}^{-1}\right)$ & $\mathrm{EF}^{\left(\mathrm{g} \mathrm{kg}^{-1}\right)}$ & $\mathrm{EF}_{\mathrm{Akagi}}\left(\mathrm{g} \mathrm{kg}^{-1}\right)$ \\
\hline $\mathbf{C}_{\mathbf{2}} \mathbf{H}_{\mathbf{6}}$ & $0.427 \pm 0.111$ & $0.906 \pm 0.195$ & $0.57 \pm 0.28$ & $0.562 \pm 0.018$ & $0.71 \pm 0.28$ & $0.325 \pm 0.026$ & $0.66 \pm 0.41$ \\
$\mathbf{H C N}$ & $0.094 \pm 0.045$ & $0.033 \pm 0.057$ & $0.89 \pm 0.29$ & $0.327 \pm 0.010$ & $0.42 \pm 0.26$ & $0.333 \pm 0.021$ & $0.41 \pm 0.15$ \\
OCS & $0.044 \pm 0.095$ & $0.053 \pm 0.018$ & $0.029 \pm 0.007$ & $0.066 \pm 0.009$ & 0.025 & $0.027 \pm 0.009$ & $\mathrm{n} / \mathrm{a}$ \\
\hline
\end{tabular}

The ACE-FTS data was converted from emission ratios (ER) with respect to $\mathrm{CO}$ to emission factors (EF) assuming the relation:

$\mathrm{EF}_{\mathrm{X}}=\mathrm{ER}_{(\mathrm{X} / \mathrm{CO})} \cdot\left(\mathrm{MW}_{\mathrm{X}} / \mathrm{MW}_{\mathrm{CO}}\right) \cdot \mathrm{EF}_{\mathrm{CO}}$

where $\mathrm{EF}_{\mathrm{X}}$ is the emission factor for the molecular species $\mathrm{X}$, $\mathrm{ER}_{(\mathrm{X} / \mathrm{CO})}$ is the molar emission ratio of the molecular species with respect to $\mathrm{CO}, \mathrm{MW}_{\mathrm{CO}}$ is the molecular weight of $\mathrm{CO}$, and $\mathrm{EF}_{\mathrm{CO}}$ is the emission factor of $\mathrm{CO}$ (Andreae and Merlet, 2001).

Table 4 lists the emission factors with respect to $\mathrm{CO}$ for $\mathrm{C}_{2} \mathrm{H}_{6}, \mathrm{HCN}$ and OCS for the Boreal forests in Canada, the tropical forests of Amazonia and the savannah in the Northern Territory of Australia. We assumed CO emission factors of 96.6(40.46) $\mathrm{g} \mathrm{kg}^{-1}, 93(27) \mathrm{g} \mathrm{kg}^{-1}$ and $63(17) \mathrm{g} \mathrm{kg}^{-1}$, respectively for $\mathrm{CO}$ for dry matter, which were the estimated average airborne values for biomass burning determined for Boreal forests, tropical forests and savannah grasslands respectively from the supplementary data provided from the study conducted by Akagi et al. (2011). The calculated emission factors for the 3 trace species were then compared to the values obtained by Akagi et al. (2011). In addition, the Boreal emission factors were also contrasted to previously made calculations from ACE-FTS measurements of Boreal fires in Alaska and Canada for these same 3 trace species (Rinsland et al., 2007). The errors calculated for the emission factors take into account that the recommended values obtained from Akagi et al. (2011) are themselves typically about $30 \%$ uncertain at the 1-sigma level and are propagated through the calculation. Emission factors determined from extensive measurements of Boreal biomass burning during the ARCTAS-B campaign (Simpson et al., 2011) were also considered for comparison purposes, however these values were used for the averaged airborne emission factors calculated by Akagi et al. (2011). For many of the species, the emission factors reported by Akagi et al. (2011) are those published by Simpson et al. (2011) such that it would be redundant to repeat the Simpson et al. (2011) data in the comparison.
Calculated values for the emission factors from this study are in good agreement to those derived from the airborne measurements used in the work by Akagi et al. (2011) and fall well within the limits of the associated errors. The only exceptions is for the emission factors of $\mathrm{HCN}$ associated with Boreal fires, where our values are an order of magnitude smaller than those reported by Akagi et al. (2011); although when compared to the emission factor obtained by Rinsland et al. (2007), our values confirm the emission factors of $\mathrm{HCN}$ previously obtained using ACE-FTS. Rinsland et al. (2007) also made note of this same discrepancy when comparing their emission factors to the results obtained from the airborne measurements conducted by Yokelson et al. (1997). Given the small number of ACE-FTS measurements used and that emission factors are being calculated using enhancement factors from plumes 2-3 days old and not from fresh biomass burning emissions from which the emission factors provide by Akagi et al. (2011) are derived, the discrepancy here is not totally unexpected.

\section{Conclusions}

Measurements of trace species from biomass burning plumes were made using the Atmospheric Chemistry Experiment Fourier Transform Spectrometer (ACE-FTS) instrument. An extensive set of molecules, $\mathrm{C}_{2} \mathrm{H}_{2}, \mathrm{C}_{2} \mathrm{H}_{6}, \mathrm{CH}_{3} \mathrm{OH}, \mathrm{CH}_{4}, \mathrm{CO}$, $\mathrm{H}_{2} \mathrm{CO}, \mathrm{HCN}, \mathrm{HCOOH}, \mathrm{HNO}_{3}, \mathrm{NO}, \mathrm{NO}_{2}, \mathrm{~N}_{2} \mathrm{O}_{5}, \mathrm{O}_{3}, \mathrm{OCS}$ and $\mathrm{SF}_{6}$ were used in our analysis. Tracer-tracer correlations were made between known pyrogenic species in these plumes in order to differentiate them and to follow their chemical evolution. The preliminary results of this investigation indicate that space-borne measurements of biomass burning emissions from different ecosystems can potentially be characterized by their unique chemical composition and that the formation and destruction of pyrogenic species can be effectively monitored.

Given the good agreement of the airborne emission factors with the remote-sensing data obtained from ACE-FTS measurements of biomass burning, we are confident that sets of age-dependent enhancements factors for a variety of biomass burning sources can be derived using the ACE-FTS dataset, 
which can serve as constraints for chemical transport models and assess the overall impact of biomass burning on atmospheric chemistry in the free troposphere.

Acknowledgements. The ACE mission is funded primarily by the Canadian Space Agency. The authors would like to thank the Natural Environment Research Council of the United Kingdom for funding K.A. Tereszchuk through Grant NE/F017391/1 and the Wild Fund for their support of G. González Abad. The authors would like to further acknowledge the Ether French atmospheric database (http://ether.ipsl.jussieu.fr) for providing the IASI L1C data.

Edited by: J. G. Murphy

\section{References}

Akagi, S. K., Yokelson, R. J., Wiedinmyer, C., Alvarado, M. J., Reid, J. S., Karl, T., Crounse, J. D., and Wennberg, P. O.: Emission factors for open and domestic biomass burning for use in atmospheric models, Atmos. Chem. Phys., 11, 4039-4072, doi:10.5194/acp-11-4039-2011, 2011.

Allen, G., Remedios, J. J., Newnham, D. A., Smith, K. M., and Monks, P. S.: Improved mid-infrared cross-sections for peroxyacetyl nitrate (PAN) vapour, Atmos. Chem. Phys., 5, 47-56, doi:10.5194/acp-5-47-2005, 2005.

Allen, N. D. C., Harrison, J. J., and Bernath, P. F.: Acetonitrile $\left(\mathrm{CH}_{3} \mathrm{CN}\right)$ infrared absorption cross sections in the $3 \mu \mathrm{m}$ region, J. Quant. Spectrosc. Ra,, 112, 1961-1966, 2011.

Alvarado, M. J., Logan, J. A., Mao, J., Apel, E., Riemer, D., Blake, D., Cohen, R. C., Min, K.-E., Perring, A. E., Browne, E. C., Wooldridge, P. J., Diskin, G. S., Sachse, G. W., Fuelberg, H., Sessions, W. R., Harrigan, D. L., Huey, G., Liao, J., Case-Hanks, A., Jimenez, J. L., Cubison, M. J., Vay, S. A., Weinheimer, A. J., Knapp, D. J., Montzka, D. D., Flocke, F. M., Pollack, I. B., Wennberg, P. O., Kurten, A., Crounse, J., Clair, J. M. St., Wisthaler, A., Mikoviny, T., Yantosca, R. M., Carouge, C. C., and Le Sager, P.: Nitrogen oxides and PAN in plumes from boreal fires during ARCTAS-B and their impact on ozone: an integrated analysis of aircraft and satellite observations, Atmos. Chem. Phys., 10, 9739-9760, doi:10.5194/acp-10-9739-2010, 2010.

Andreae, M. O. and Merlet, P.: Emission of trace gases and aerosols from biomass burning, Global Biogeochem. Cy., 15, 955-966, doi:910.1029/2000GB001382, 2001.

Arino, O. and Plummer, S.: Along Track Scanning Radiometer World Fire Atlas: Validation of the 1997-98 Active Fire Product, Validation report, IGBP-DIS Working Pap. 23, Int. Geosph. Biosph. Progr., Stockholm, http://due.esrin.esa.int/ wfareferences.php, 2001.

Bernath, P. F., McElroy, C. T., Abrams, M. C., Boone, C. D., Butler, M., Camy-Peyret, C., Carleer, M. , Clerbaux, C., Coheur, P.-F., Colin, R., DeCola, P., DeMazière, M., Drummond, J. R., Dufour, D., Evans, W. F. J., Fast, H., Fussen, D., Gilbert, K., Jennings, D. E., Llewellyn, E. J., Lowe, R. P., Mahieu, E., McConnell, J. C., McHugh, M., McLeod, S. D., Michaud, R., Midwinter, C., Nassar, R., Nichitiu, F., Nowlan, C., Rinsland, C. P., Rochon, Y. J., Rowlands, N., Semeniuk, K., Simon, P., Skelton, R., Sloan, J. J., Soucy, M.-A., Strong, K., Tremblay, P., Turnbull, D., Walker, K.
A., Walkty, I., Wardle, D. A., Wehrle, V., Zander, R., and Zou, J.: Atmospheric Chemistry Experiment (ACE): Mission overview, Geophys. Res. Lett., 32, L15S01, doi:10.1029/2005GL022386, 2005.

Boone, C. D., Nassar, R., Walker, K. A., Rochon, Y., McLeod, S. D., Rinsland, C. P., and Bernath, P. F.: Retrievals for the atmospheric chemistry experiment Fourier-transform spectrometer, Appl. Optics, 44, 7218-7231, 2005.

Burling, I. R., Yokelson, R. J., Akagi, S. K., Urbanski, S. P., Wold, C. E., Griffith, D. W. T., Johnson, T. J., Reardon, J., and Weise, D. R.: Airborne and ground-based measurements of the trace gases and particles emitted by prescribed fires in the United States, Atmos. Chem. Phys. Discuss., 11, 18677-18727, doi:10.5194/acpd-11-18677-2011, 2011.

Clerbaux, C., Boynard, A., Clarisse, L., George, M., Hadji-Lazaro, J., Herbin, H., Hurtmans, D., Pommier, M., Razavi, A., Turquety, S., Wespes, C., and Coheur, P.-F.: Monitoring of atmospheric composition using the thermal infrared IASI/MetOp sounder, Atmos. Chem. Phys., 9, 6041-6054, doi:10.5194/acp-9-6041-2009, 2009.

Coheur, P.-F., Herbin, H., Clerbaux, C., Hurtmans, D., Wespes, C., Carleer, M., Turquety, S., Rinsland, C. P., Remedios, J., Hauglustaine, D., Boone, C. D., and Bernath, P. F.: ACE-FTS observation of a young biomass burning plume: first reported measurements of $\mathrm{C}_{2} \mathrm{H}_{4}, \mathrm{C}_{3} \mathrm{H}_{6} \mathrm{O}, \mathrm{H}_{2} \mathrm{CO}$ and PAN by infrared occultation from space, Atmos. Chem. Phys., 7, 5437-5446, doi:10.5194/acp-75437-2007, 2007.

Coheur, P.-F., Clarisse, L., Turquety, S., Hurtmans, D., and Clerbaux, C.: IASI measurements of reactive trace species in biomass burning plumes, Atmos. Chem. Phys., 9, 5655-5667, doi:10.5194/acp-9-5655-2009, 2009.

Crutzen, P. J., Heidt, L. E., Krasnec, J. P., Pollock, W. H., and Seiler, W.: Biomass burning as a source of atmospheric gases $\mathrm{CO}, \mathrm{H}_{2}$, $\mathrm{N}_{2} \mathrm{O}, \mathrm{NO}, \mathrm{CH}_{3} \mathrm{Cl}$, and COS, Nature, 282, 253-256, 1979.

Crutzen, P. J. and Andreae, M. O.: Biomass burning in the tropics: Impact on atmospheric chemistry and biogeochemical cycles, Science, 250, 1669-1678, 1990.

Draxler, R. R. and Rolph, G. D.: HYSPLIT (HYbrid SingleParticle Lagrangian Integrated Trajectory) Model, NOAA Air Resources Laboratory, Silver Spring, MD, available at: http: //www.arl.noaa.gov/ready/hysplit4.html, 2003.

Fiedler, V., Arnold, F., Ludmann, S., Minikin, A., Hamburger, T., Pirjola, L., Dörnbrack, A., and Schlager, H.: African biomass burning plumes over the Atlantic: aircraft based measurements and implications for $\mathrm{H}_{2} \mathrm{SO}_{4}$ and $\mathrm{HNO}_{3}$ mediated smoke particle activation, Atmos. Chem. Phys., 11, 3211-3225, doi:10.5194/acp-11-3211-2011, 2011.

George, M., Clerbaux, C., Hurtmans, D., Turquety, S., Coheur, P.F., Pommier, M., Hadji-Lazaro, J., Edwards, D. P., Worden, H., Luo, M., Rinsland, C., and McMillan, W.: Carbon monoxide distributions from the IASI/METOP mission: evaluation with other space-borne remote sensors, Atmos. Chem. Phys., 9, 8317-8330, doi:10.5194/acp-9-8317-2009, 2009.

Glatthor, N., von Clarmann, T., Stiller, G. P., Funke, B., Koukouli, M. E., Fischer, H., Grabowski, U., Höpfner, M., Kellmann, S., and Linden, A.: Large-scale upper tropospheric pollution observed by MIPAS HCN and $\mathrm{C}_{2} \mathrm{H}_{6}$ global distributions, Atmos. Chem. Phys., 9, 9619-9634, doi:10.5194/acp-9-9619-2009, 2009. 
Harrison, J. J. and Bernath, P. F.: Mid- and long-wave infrared absorption cross sections for acetonitrile, J. Quant. Spectrosc. Ra., doi:10.1016/j.jqsrt.2011.11.003, in press, 2011.

Hobbs, P. V., Sinha, P., Yokelson, R. J., Christian, T. J., Blake, D. R., Gao, S., Kirchstetter, T. W., Novakov, T., and Pilewskie, P.: Evolution of gases and particles from a savanna fire in South Africa, J. Geophys. Res., 108, 8485, doi:10.1029/2002JD002352, 2003.

Koppmann, R., von Czapiewski, K., and Reid, J. S.: A review of biomass burning emissions, part I: gaseous emissions of carbon monoxide, methane, volatile organic compounds, and nitrogen containing compounds, Atmos. Chem. Phys. Discuss., 5, 1045510516, doi:10.5194/acpd-5-10455-2005, 2005.

Manney, G. L., Daffer, W. H., Zawodny, J. M., Bernath, P. F., Hoppel, K. W.,Walker, K. A., Knosp, B. W., Boone, C., Remsberg, E. E., Santee, M. L., Harvey, V. L., Pawson, S., Jackson, D. R., Deaver, L., McElroy, C. T., McLinden, C. A., Drummond, J. R., Pumphrey, H. C., Lambert, A., Schwartz, M. J., Froidevaux, L., McLeod, S., Takacs, L. L., Suarez, M. J., Trepte, C. R., Cuddy, D. C., Livesey, N. J., Harwood, R. S., and Waters, J. W. : Solar occultation satellite data and derived meteorological products: sampling issues and comparisons with Aura MLS, J. Geophys. Res., 112, D24S50, doi:10.1029/2007JD008709, 2007.

Lefer, B. L., Talbot R. W., Harriss, R. H., Bradshaw, J. D., Sandholm, S. T., Olson, J. O., Sachse, G. W., Collins, J., Shipham, M. A., Blake, D. R., Klemm, K. I., Klemm, O., Gorzelska, K., and Barrick, J.: Enhancement of acidic gases in biomass burning impacted air masses over Canada, J. Geophys. Res., 99, 1721-1737, 1994.

Li, Q., Jacob, D. J., Yantosca, R. M., Heald, C. L., Singh, H. B., Koike, M., Zhao, Y., Sachse, G. W., and Streets, D. G.: A global three-dimensional model analysis of the atmospheric budgets of $\mathrm{HCN}$ and $\mathrm{CH}_{3} \mathrm{CN}$ : Constraints from aircraft and ground measurements, J. Geophys. Res., 108, 8827, doi:10.1029/2002JD003075, 2003.

Rinsland, C. P., Dufour, G., Boone, C. D., Bernath, P. F., and Chiou, L.: Atmospheric Chemistry Experiment (ACE) measurements of elevated Southern Hemisphere upper tropospheric CO, $\mathrm{C}_{2} \mathrm{H}_{6}, \mathrm{HCN}$, and $\mathrm{C}_{2} \mathrm{H}_{2}$ mixing ratios from biomass burning emissions and long-range transport, Geophys. Res. Lett., 32, L20803, doi:10.1029/2005GL024214, 2005.

Rinsland, C. P., Dufour, G., Boone, C. D., Bernath, P. F., Chiou, L., Coheur, P. -F., Turquety, S., and Clerbaux, C.: Satellite boreal measurements over Alaska and Canada during JuneJuly 2004: Simultaneous measurements of upper tropospheric $\mathrm{CO}, \mathrm{C}_{2} \mathrm{H}_{6}, \mathrm{HCN}, \mathrm{CH}_{3} \mathrm{Cl}, \mathrm{CH}_{4}, \mathrm{C}_{2} \mathrm{H}_{2}, \mathrm{CH}_{3} \mathrm{OH}, \mathrm{HCOOH}$, OCS, and $\mathrm{SF}_{6}$ mixing ratios, Global Biogeochem. Cy., 21, doi:10.1029/2006GB002795, 2007.

Simpson, I. J., Akagi, S. K., Barletta, B., Blake, N. J., Choi, Y., Diskin, G. S., Fried, A., Fuelberg, H. E., Meinardi, S., Rowland, F. S., Vay, S. A., Weinheimer, A. J., Wennberg, P. O., Wiebring, P., Wisthaler, A., Yang, M., Yokelson, R. J., and Blake, D. R.: Boreal forest fire emissions in fresh Canadian smoke plumes: C1-C10 volatile organic compounds (VOCs), $\mathrm{CO}_{2}, \mathrm{CO}, \mathrm{NO}_{2}$, $\mathrm{NO}, \mathrm{HCN}$ and $\mathrm{CH}_{3} \mathrm{CN}$, Atmos. Chem. Phys., 11, 6445-6463, doi:10.5194/acp-11-6445-2011, 2011.
Singh, H. B., Salas, L., Herlth, D., Kolyer, R., Czech, E., Viezee, W., Li, Q., Jacob, D. J., Blake, D., Sachse, G., Harward, C. N., Fuelberg, H., Kiley, C. M., Zhao, Y., and Kondo, Y.: In situ measurements of $\mathrm{HCN}$ and $\mathrm{CH}_{3} \mathrm{CN}$ over the Pacific Ocean: Sources, sinks, and budgets, J. Geophys. Res., 108, 8795, doi:10.1029/2002JD003006, 2003.

Stubenrauch, C. J., Cros, S., Guignard, A., and Lamquin, N.: A 6-year global cloud climatology from the Atmospheric InfraRed Sounder AIRS and a statistical analysis in synergy with CALIPSO and CloudSat, Atmos. Chem. Phys., 10, 7197-7214, doi:10.5194/acp-10-7197-2010, 2010.

Torres, O., Chen, Z., Jethva, H., Ahn, C., Freitas, S. R., and Bhartia, P. K.: OMI and MODIS observations of the anomalous 20082009 Southern Hemisphere biomass burning seasons, Atmos. Chem. Phys., 10, 3505-3513, doi:10.5194/acp-10-3505-2010, 2010.

Tereszchuk, K. A., and Bernath, P. F.: Infrared absorption crosssections for acetaldehyde $\left(\mathrm{CH}_{3} \mathrm{CHO}\right)$ in the $3 \mu \mathrm{m}$ region, $\mathrm{J}$ Quant. Spectrosc. Ra., 112, 990-993, 2011.

Turquety, S., Hurtmans, D., Hadji-Lazaro, J., Coheur, P.-F., Clerbaux, C., Josset, D., and Tsamalis, C.: Tracking the emission and transport of pollution from wildfires using the IASI CO retrievals: analysis of the summer 2007 Greek fires, Atmos. Chem. Phys., 9, 4897-4913, doi:10.5194/acp-9-4897-2009, 2009.

Yokelson, R. J., Susott, R. A., Ward, D. E., Reardon, J., and Griffith, D. W. T.: Emissions from smoldering combustion of biomass measured by open-path Fourier transform infrared spectroscopy, J. Geophys. Res., 102, 18865-18877, 1997.

Yokelson, R. J., Bertschi, I. T., Christian, T. J., Hobbs, P. V., Ward, D. E., and Hao, W. M.: Trace gas measurements in nascent, aged, and cloud-processed smoke from African savanna fires by airborne Fourier transform infrared spectroscopy (AFTIR), J. Geophys. Res., 108, 8478, doi:10.1029/2002JD002322, 2003.

Yokelson, R. J., Urbanski, S. P., Atlas, E. L., Toohey, D. W., Alvarado, E. C., Crounse, J. D., Wennberg, P. O., Fisher, M. E., Wold, C. E., Campos, T. L., Adachi, K., Buseck, P. R., and Hao, W. M.: Emissions from forest fires near Mexico City, Atmos. Chem. Phys., 7, 5569-5584, doi:10.5194/acp-7-5569-2007, 2007a.

Yokelson, R. J., Karl, T., Artaxo, P., Blake, D. R., Christian, T. J., Griffith, D. W. T., Guenther, A., and Hao, W. M.: The Tropical Forest and Fire Emissions Experiment: overview and airborne fire emission factor measurements, Atmos. Chem. Phys., 7, 5175-5196, doi:10.5194/acp-7-5175-2007, 2007b.

Yokelson, R. J., Crounse, J. D., DeCarlo, P. F., Karl, T., Urbanski, S., Atlas, E., Campos, T., Shinozuka, Y., Kapustin, V., Clarke, A. D., Weinheimer, A., Knapp, D. J., Montzka, D. D., Holloway, J., Weibring, P., Flocke, F., Zheng, W., Toohey, D., Wennberg, P. O., Wiedinmyer, C., Mauldin, L., Fried, A., Richter, D., Walega, J., Jimenez, J. L., Adachi, K., Buseck, P. R., Hall, S. R., and Shetter, R.: Emissions from biomass burning in the Yucatan, Atmos. Chem. Phys., 9, 5785-5812, doi:10.5194/acp-9-5785-2009, 2009. 